\title{
STRATEGI GRUP BARONG SARDULO KRIDA MUSTIKA DALAM MELESTARIKAN SENI BARONGAN BLORA
}

\author{
THE STRATEGY OF BARONG GROUP SARDULO KRIDA \\ MUSTIKA IN CONSERVING \\ BARONGAN ARTS OF BLORA
}

\author{
Hamidulloh Ibda \\ STAINU Temanggung \\ Jln. Suwandi-Suwardi KM. 1 Madureso, Temanggung, Jawa Tengah \\ h.ibdaganteng@stainutmg.ac.id
}

Diterima tanggal 2 Januari 2019

Disetujui tanggal 13 Juni 2019

\begin{abstract}
Blora regency has been initiated as the "City of Barong" since 2009. Barong has been designated as an the intangible heritage by the government. In addition to the government's efforts, strategies and innovations of the barong group to conserve the local culture are still necessary. This study aimed to describe the strategies of Sardulo Krida Mustika group in preserving barong art of Blora Regency, Central Java. This study used descriptive qualitative analysis by presenting factual information of Sardulo Krida Mustika group in Blora Regency. Sardulo Krida Mustika took nine strategies to conserve barongan Blora. First, utilizing technology. Second, collaborating with cyber media. Third, embellishing the design of barong which adjusts to the current trend to be more attractive. Fourth, introducing barong crafts independently in group members. Fifth, accentuating the educational side rather than commercial and financial sides. Sixth, cooperating with another barong group by involving one, or two people in their performance. Seventh, increasing the number of members from the elements of children, pupil, and university students. Eighth, making barong art activities for bussiness and training the economic autonomy. Ninth, collaborating and establishing communication with Blora's student organizations and foreigners, in Blora, Java, Jakarta, outside Java and even overseas.
\end{abstract}

Keyword: barong Blora, barong arts, Sardulo Krida Mustika, and conservation of cultural values.

\begin{abstract}
ABSTRAK
Kabupaten Blora telah digagas sebagai "Kota Barong" sejak 2009. Kesenian ini sudah ditetapkan sebagai Warisan Budaya Takbenda oleh pemerintah. Selain usaha dari pemerintah, perlu strategi dan inovasi dari grup barong dalam melestarikan budaya lokal tersebut. Penelitian ini bertujuan menggambarkan strategi grup Sardulo Krida Mustika dalam
\end{abstract}


melestarikan seni barong khas Kabupaten Blora, Jawa Tengah. Penelitian ini menggunakan analisis deskriptif kualitatif dengan menggambarkan informasi faktual grup barong Sardulo Krida Mustika di Kabupaten Blora. Terdapat sembilan langkah strategi yang dilakukan Sardulo Krida Mustika untuk melestarikan barongan Blora. Pertama, memanfaatan teknologi. Kedua, melakukan kerjasama dengan media siber. Ketiga, mengikuti perkembangan zaman dengan cara memoles desain barong yang menarik. Keempat, merintis kerajinan barong secara mandiri pada anggota grup. Kelima, mengutamakan sisi edukasi daripada komersil dan uang. Keenam, kerjasama dengan grup barong lain dengan cara mengambil satu, atau dua orang saat ada pentas. Ketujuh, memperbanyak anggota dari unsur anak-anak, pelajar, dan mahasiswa. Kedelapan, menjadikan aktivitas seni barong untuk berbinis dan melatih kemandirian secara ekonomi. Kesembilan, bekerjasama, menjalin komunikasi dengan organisasi mahasiswa dan perantau Blora, baik di wilayah Blora, Jawa, Jakarta, luar Jawa bahkan di luar negeri.

Kata kunci : barong Blora, kesenian barong, Sardulo Krida Mustika, dan pelestarian Nilai budaya.

\section{A. PENDAHULUAN}

Blora sebagai salah satu kabupaten di Jawa Tengah memiliki kesenian barong atau barongan yang menjadi khazanah budaya lokal. Selain dikenal dengan sebutan Kota Samin atau Bumi Samin, Kota Sate, Kota Kayu Jati, dan Kota Kelahiran Sastrawan Pramoedya Ananta Toer, Blora juga dideklarasikan sebagai Blora Kota Barong. Blora memiliki seni barongan yang dari tahun ke tahun mengalami akselerasi yang pesat. Sejak 2009, dideklarasikan sebagai Kota Barong yang kini mulai dikenal di Indonesia.

Dalam menghadapi tantangan disrupsi budaya di era Revolusi Industri 4.0 ini tentu harus ada strategi pelestarian seni barong. Mulai dari unsur pemerintah, sanggar, grup, atau seniman barongan itu sendiri agar budaya lokal ini tetap lestari dan mendunia. Pelestarian ini juga berdampak pada legitimasi budaya agar tidak ada klaim budaya oleh negara lain.

Sejak tahun 2009, lebih dari 600 seniman barongan melakukan deklarasi "Blora Kota Barongan" (Fauzin, 2014). Sejak tahun 2014, Blora juga telah menggelar Festival Barong dengan berbagai tema tingkat nasional yang mengangkat "gengsi" seni barong. Kemudian pada tahun 2017, barongan Blora semakin taji, bergengsi, dan menasional karena sudah diakui oleh pemerintah, baik Kementerian Pendidikan dan Kebudayaan (Kemdikbud) RI dan Dinas Pendidikan dan Kebudayaan Provinsi Jawa Tengah.

Setelah melalui tahapan seleksi dan pengajuan yang panjang, seni pertunjukan rakyat barongan Blora mendapatkan pengakuan dari Kemendikbud RI dan Dinas Pendidikan dan Kebudayaan Jawa Tengah sebagai Warisan Budaya Takbenda (WBTB). Pengakuan secara resmi tersebut ditandai dengan terbitnya sertifikat 
Kemendikbud RI yang diberikan kepada Pemerintah Kabupaten Blora pada malam acara Festival Barong Nusantara IV Tahun 2017, yaitu pada 5 Desember 2017 (www.infoblora.com/ 2017/12/barongan-blora-resmi-diakuisebagai.html, diakses pada 29 Desember 2018).

Pengakuan ini tentu bukan tanpa alasan. Barongan menjadi satu kesenian unik yang harus dilestarikan karena sarat akan nilai-nilai kearifan lokal. Pengakuan tersebut bukan menjadi tujuan akhir dari upaya melestarikan kesenian lokal. Tantangan zaman pada abad ke-21 yang semakin kompleks mengharuskan adanya inovasi, promosi, dan strategi agar generasi muda tidak tercerabut dari budayanya sendiri.

Hingga Agustus 2016, Badan Pengembangan dan Pembinaan Bahasa Kemdikbud mencatat 15 bahasa daerah di Indonesia telah punah dan sebanyak 139 terancam lenyap (Wiyono, 2016). Hingga tahun 2017, Tribunnews.com mencatat ada 10 adat istiadat unik khas Nusantara hampir punah. Mulai dari mapasilaga tedong di Toraja, tabuik Sumatera Barat, ritual tiwah di Kalimantan Tengah, tradisi pemakaman suku Minahasa di Sulawesi Utara, tradisi potong jari di Papua, dan batombe di Sumatera Barat (Purwaningrum, 2017). Pusat Studi Kebudayaan UGM, pada 2013 juga mencatat budaya tradisional asli Indonesia khususnya Daerah Istimewa Yogyakarta (DIY) kondisinya mulai ironis. Seperti, di Kabupaten Sleman ada sekitar 200 budaya tradisional sudah punah dan ada yang hampir punah (Keswara, 2013).

Di Kabupaten Blora sendiri, ada beberapa seni tradisional yang dalam kondisi darurat; seperti seni tayub, tembang jedor, seni kentrung dan wayang krucil (Sutomo, 2008). Seni hadrah, rebana, atau jedoran khas Blora juga hampir punah ditelan zaman (http:/ /www.infoblora.com/2013/05/jedoranrebana-tradisional-khas-blora.html, diakses pada 28 Desember 2018). Jika dibiarkan, lambat laun tradisi, budaya, dan bahasa daerah di Nusantara ini akan lenyap dan tidak ada penerusnya. Salah satunya adalah barongan Blora sebagai salah satu kekayaan budaya di Jawa Tengah.

Dari catatan Statistik Kebudayaan 2016 Pusat Data dan Statistik Pendidikan dan Kebudayaan Kemdikbud RI, Jawa Tengah memiliki 401 Warisan Budaya Takbenda (the Intangible Heritage). Jawa Barat memiliki 437 dan Jawa Timur memiliki 479 Warisan Budaya Takbenda (Kemdikbud, 2016:10). Sebagai provinsi ketiga yang memiliki Warisan Budaya Takbenda terbanyak di Indonesia, Jawa Tengah harus memiliki strategi pelestarian warisan budaya agar tidak punah.

Barongan sebagai salah satu warisan leluhur harus dijaga kelestariannya. Barongan merupakan kesenian rakyat khas Jawa Tengah. Kabupaten Blora-lah yang secara kuantitas, memiliki warisan budaya yang lebih banyak dan mempunyai 
kekhasan tersendiri dibandingkan dengan kabupaten lain. Dalam kesenian barongan, tercermin sifatsifat kerakyatan masyarakat setempat, mulai spontanitas, kekeluargaan, kesederhanaan, kasar, keras, kompak, dan keberanian yang dilandasi kebenaran (Nugroho, 2017).

Dari penjelasan di atas, diperlukan langkah strategis untuk melestarikan seni barongan Blora sebagai salah satu kesenian unik di Jawa Tengah bahkan di Indonesia. Langkah pelestarian ini tentu tidak berhenti dan hanya dibebankan pada pemerintah. Seniman dan grup barongan Blora sangat berperan penting dalam melestarikannya melalui cara atau strategi yang mereka lakukan sesuai kapasitas dan keunikannya masing-masing di tiap daerah. Hal itu semakin urgen karena sejumlah kesenian tradisional khas Blora lambat laun mulai punah. Bahkan, generasi muda tidak tahu bahwa Kabupaten Blora memiliki seniseni menarik, unik, dan sarat akan nilainilai luhur yang sangat laik diterapkan dalam kehidupan sehari-hari.

Berdasarkan uraian tersebut di atas, penelitian ini mengkaji: pertama, bagaimana sejarah dan perkembangan seni barong di Blora? Kedua, bagaimana profil grup barong Sardulo Krida Mustika? Ketiga, bagaimana strategi yang dilakukan grup barong Sardulo Krida Mustika dalam melestarikan seni barongan Blora?.

\section{B. METODE}

Penelitian ini dilaksanakan di Blora dengan berfokus pada grup barong, Sardulo Krida Mustika. Metode dalam penelitian ini menggunakan penelitian kualitatif. Penelitian ini menggambarkan secara sistematis dan komprehensif strategi grup barong Sardulo Krida Mustika dalam melestarikan seni barong di Blora. Tujuan dari penelitian ini ada dua. Pertama, menggambarkan sejarah dan perkembangan seni barong di Blora. Kedua, menggambarkan profil grup barong Sardulo Krida Mustika. Ketiga, menggambarkan strategi yang dilakukan grup barong Sardulo Krida Mustika dalam melestarikan seni barongan Blora.

Data dalam penelitian ini sumber dari data primer dan data sekunder. Data primer dalam penelitian ini merupakan data yang langsung diperoleh dari informan berdasarkan wawancara. Informan dalam penelitian ini ialah pengurus grup barong Sardulo Krida Mustika. Data sekundernya yaitu berupa data-data hasil penelitian sebelumnya, foto, dokumentasi pertunjukan barongan, dokumen program kerja pengurus barongan Sardulo Krida Mustika serta catatan sejarah yang relevan dengan tujuan penelitian ini.

Teknik pengumpulan data yang digunakan ialah observasi, wawancara, dan dokumentasi terkait grup Sardulo Krida Mustika. Pengumpulan data dilakukan pada 15 Desember 2018 sampai 30 Desember 2018. 
Penelitian menggunakan analisis data kualitatif dengan melakukan enam langkah. Pertama, mengolah data dan mengintrepretasikan data untuk dianalisis. Kedua, membaca keseluruhan data. Ketiga, menganalisis lebih detail dengan mengodekan data. Keempat, menerapkan pengodean untuk mendeskripsikan latar (setting), orang-orang, kategori, dan tema-tema yang akan dianalisis. Kelima, menunjukkan bagaimana deskripsi dan tema-tema ini akan disajikan kembali dalam narasi atau laporan kualitatif. Keenam, menginterpretasi atau memaknai data (Creswell, 2009: 276283).

Langkah-langkah di atas diterapkan dalam penelitian ini dengan menulis data dari wawancara kemudian dikoding, dipilah sesuai tema-tema, selanjutnya peneliti menginterpretasi data yang diperoleh dari grup Sardulo Krida Mustika.

\section{HASIL DAN BAHASAN}

\section{Sejarah dan Perkembangan Seni Barongan Blora}

Barong atau biasa disebut barongan Blora merupakan salah satu kesenian lokal khas Jawa Tengah yang paling banyak ditemui di Kabupaten Blora. Kesenian ini memiliki keunikan, perbedaan dengan barong di daerah lain bahkan dengan reog Ponorogo, Jawa Timur. Secara historis, barongan Blora, tidak dapat ditentukan kepastiannya. Namun ada sejumlah sumber cerita, legenda, baik tertulis atau lisan yang dapat dijadikan rujukan dan sudah diyakini pemerintah sebagai asal-usul barongan Blora.

Legenda barongan Blora berawal dari seorang Naya Gimbal pengikut Pangeran Diponegoro yang bersembunyi di Desa Sambeng. Kala itu Belanda datang dan mencari warga Sambeng. Bersamaan dengan hal itu, warga Sambeng sedang mengarak pengantin, dan mereka naik dokar dengan diiringi barongan, jedor, dan terbang. Orang-orang di sana, kala itu ditembaki oleh Belanda (Hutomo, 1996: 4).

Hadirnya barongan Blora sangat erat kaitannya dengan mitologi pada binatang. Dalam sejarah budaya oral warga Blora, hadirnya barongan Blora dikaitkan dengan makam tua di Kelurahan Mlangsen, Blora, yang dipercaya sebagai makam Singa Lodra atau Singo Lodro. Di makam tersebut, dipercaya sering muncul harimau besar jelmaan Mbah Singa Lodra. Sumber lain dari tradisi lisan warga Blora, menyebut barongan merupakan jelmaan orang bernama Gambong Amijoyo dalam cerita "Panji."

Catatan Pemerintah kabupaten Blora, seni barongan bersumber dari "Hikayat Panji." Hikayat ini merupakan cerita yang diawali dari iringiringan prajurit berkuda mengawal Raden Panji Asmarabangun atau Pujonggo Anom dan Singo Barong (www.blorakab.go.id/index.php/public/ kebudayaan/detail/59/senianbarong\%0A, diakses pada 28 Desember 2018). Dalam hikayat itu, adanya arakarakan yang dipimpin Singo Barong 
Handep, Vol.2, No. 2, Juni 2019

dan Bujangganong inilah yang menjadi latar belakang keberadaan kesenian barongan yang kini berkembang di Blora.

Seni barongan merupakan kesenian asli khas Blora yang menceritakan tentang dua sosok sakti yang bernama Gembong Amijoyo dan Joko Lodro. Cerita yang diangkat dalam barongan menjadi ciri khas dari barongan Blora. Gembong Amijoyo merupakan sosok sakti yang dapat mengubah diri menjadi harimau raksasa, di dalam cerita barongan sering disebut barongan atau barong.

Tugas Gembong Amijoyo dalam cerita ini menjaga Alas Jati Wengker. Para pengamat kesenian, menjelaskan Alas Jati Wengker terletak di Blora, karena pengertian dari Alas Jati Wengker yaitu hutan jati terbaik di dunia. Blora sendiri menjadi daerah yang memiliki kekayaan alam berupa hutan jati terbaik di dunia, maka dari pengamatan ahli kesenian tersebut dapat disimpulkan bahwa Alas Jati Wengker adalah hutan jati di Blora yang sudah ada sebelum Blora terbentuk. Pengamatan tentang Alas Jati Wengker itu dapat menjadi bukti kesenian barongan merupakan kesenian asli Blora yang sudah terjadi sebelum Blora terbentuk dan diwujudkan menjadi bentuk kesenian oleh masyarakat Blora sebagai ciri khas Blora (Bintartiwi, 2014: 24-26).

Selain Gembong Amijoyo, ada sosok Joko Lodro yang merupakan orang sakti karena dapat mengubah wujud diri menjadi sosok raksasa. Joko Lodro di dalam cerita barongan sering disebut Gendruwon yang ditugaskan menjaga Kerajaan Janggala yang berada Kediri dan dipimpin seorang raja yaitu Panji Asmara Bangun.

Gembong Amijoyo memiliki prinsip "aku bakalan njogo alas wengker sak isine" (saya akan menjaga seluruh isi hutan jati wengker). Gembong Amijoyo memiliki kakak seperguruan bernama Joko Lodro yang tinggal di kerajaan. Dalam cerita "Panji", Panji Asmara Bangun mempunyai keinginan untuk melamar Dewi Sekartaji. Untuk melamar Dewi Sekartaji, jalan yang paling cepat adalah melewati Alas Jati Wengker.

Kemudian, Panji mengutus Patih Pujangga Anom yang dalam cerita barongan menjadi Bujangganong beserta pasukan berkuda yang dalam cerita barongan digambarkan menjadi jaranan. Pasukan berkuda membawa pengikut yang di dalam cerita barongan disebut Nayantaka dan Gainah. Selanjutnya, Bujangganong dengan pengawalan pasukan berkuda yang diikuti Nayantaka dan Gainah dalam cerita barongan diwujudkan sebagai Pentulan pergi memasuki Alas Jati Wengker.

Setelah memasuki Alas Jati Wengker, Bujangganong dan pasukan berkuda bertemu dengan Gembong Amijoyo. Sesuai dengan sumpah tugasnya Gembong Amijoyo melarang Bujangganong berserta pengawalnya memasuki Alas Jati Wengker. Sebab, ketika Bujangganong dan pengawalnya melewati Alas Jati Wengker, maka 
kekayaan alam berserta isi Alas Jati Wengker akan habis. Lantaran tidak diperbolehkan Gembong Amijoyo melewati hutan itu, lalu terjadilah perkelahian antara Gembong Amijoyo dengan Bujangganong.

Dalam perkelahian itu, Bujanggangong mengalami kekalahan. Nayantoko dan Gainah mengingatkan Gembong Amijoyo bahwa ia memiliki kakak seperguruan yang bertugas di Kerajaan Janggala bernama Joko Lodro. Setelah kalah, pengawal Bujangganong kembali ke kerajaan memberitahukan peristiwa itu kepada Panji Asmara Bangun. Mengingat Joko Lodro merupakan kakak seperguruan Gembong Amijoyo, Panji memberikan perintah kepada Joko Lodro untuk menemui Gembong Amijoyo di Alas Jati Wengker (Bintartiwi, 2014: 26).

Ketika sampai di Alas Jati Wengker, Joko Lodro dan Gembong Amijoyo bertemu. Kedua bersaudara itu memiliki tugas masing-masing, Joko Lodro untuk Kerajaan Janggala, Gembong Amijoyo bertugas menjaga Alas Jati Wengker. Pertikaian antara kakak adik tidak dapat dihindari, karena mereka menjalankan tugas masing-masing.

Dalam pertikaian tersebut, Gembong Amijoyo mengalami kekalahan, namun karena kesaktian yang ia miliki Gembong Amijoyo tetap bertahan hidup. Gembong Amijoyo berbicara dengan Joko Lodro, "Mas, yen ono sing isa ngalahke aku, rombonganmu iso nglewati alas iki kanggo nglamar Dewi Sekartaji, nanging alas iki bakal rusak" (Mas, apabila ada yang bisa mengalahkanku, rombonganmu dapat melewati hutan ini untuk melamar Dewi Sekartaji, tetapi hutan ini akan mengalami kerusakan).

Perkataan Gembong Amijoyo kepada Joko Lodro terbukti. Pada saat ini, hutan jati yang berada di Blora mengalami kepunahan karena kayu jati digunakan untuk memenuhi kebutuhan pihak dari luar Blora, seperti pembuatan perabotan rumah tangga, industri, dan lainnya. Jika melihat cerita Gembong Amijoyo dan Joko Lodro, mereka berdua bersaudara dan mengalami pertikaian karena Joko Lodro memilih berpihak kepada Kerajaan Jenggala, Panji Asmara Bangun daripada saudara seperguruan Joko Lodro, yaitu Gembong Amijoyo (Bintartiwi, 2014: 27).

Versi lain menyebut, sebelum masa penjajahan Belanda, sekitar abad ke-16, Blora berada di bawah kekuasaan Kerajaan Jipang. Masyarakat berusaha untuk menceritakan kembali pertikaian antara Gembong Amijoyo dan Joko Lodro dalam wujud seni tari.

Tarian Barongan menceritakan alur peristiwa pertikaian antara Gembong Amijoyo, Bujangganong dan Joko Lodro yang diceritakan dalam cerita Panji. Tarian yang diciptakan masyarakat berdasarkan urut-urutan kejadian pertikaian, yang dimulai dengan perkenalan tokoh Gembong Amijoyo dan Joko Lodro, pertemuan dan pertikaian antara Gembong Amijoyo dengan Bujangganong, kembalinya pengawal Bujangganong 
Handep, Vol.2, No. 2, Juni 2019

(Jaranan dan Penthul) ke kerajaan, dan pertikaian antara Gembong Amijoyo dengan Joko Lodro yang berakhir dengan kekalahan yang dialami Gembong Amijoyo. Gerak tari barongan cenderung gerakan yang bersemangat, tidak terikat dengan iringan musik karena menggambarkan pertikaian yang bersifat spontanitas (Bintartiwi, 2014: 27-28).

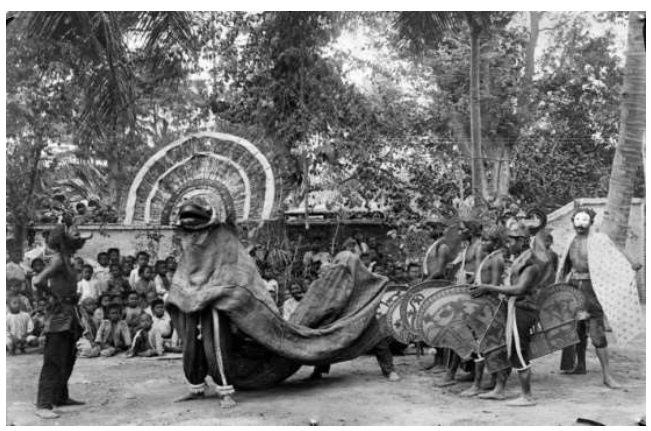

Gambar 1. Bentuk barong Blora saat ini yang menyerupai barong Ponorogo tahun 1920.

Sumber: https://id.wikipedia.org/wiki/ Barongan_Gembong_Amijoyo, diakses pada Desember 2018.

Secara ilmiah, dari legenda tertulis di atas, dapat dikatakan seni barong Blora sudah ada sekitar tahun 1830. Hal itu terbukti pada penggunaan barongan dalam setiap upacara atau arak-arakan pengantin pada masa Naya Gimbal yang terjadi di era masa Perang Diponegoro sekitar tahun 1825-1830 (Soedarsono, 1999: 195).

Sumber lain menyebut, sejarah barongan Blora dimulai kesenian barong di Kerajaan Kadiri, Jawa Timur antara tahun 1042-1222. Pada saat itu, biaya membuat kepala barong menggunakan bulu merak dianggap mahal dan sulit untuk mendapatkannya, maka saat orang Blora membuat barong, hanya menggunakan kulit sapi, kambing, dan lainnya yang lebih murah. Barongan Blora merupakan representasi wujud perlawanan masyarakat Blora pada saat itu. Dikarenakan masyarakat Blora ingin menikmati tradisi unik tersebut, maka lahir dan terciptalah kesenian khas Blora, yaitu seni barong yang berbeda dengan reog Ponorogo (http:/ /www.harianblora.com/2014/12/ inilah-perbedaan-barongan-bloradengan.html, diakses pada 27 Desember 2018). Saat ini, barongan Blora masih menjadi salah satu seni yang masih eksis di antar beberapa seni lain yang hampir bahkan sudah punah.

Barongan Blora merupakan kesenian kerakyatan asli Kabupaten Blora, Jawa Tengah. Bentuk dari kesenian ini adalah berupa pertunjukan tari yang di dalamnya menampilkan tokoh barongan atau Gembong Amijoyo, Bujang Ganong, Joko Lodro atau Gendruwon, Untup, Nayantaka, Gainah, dan Jaranan atau Jatilan. Setiap grup memiliki komposisi yang berbeda dalam menampilkan pertunjukan barongan Blora ini. Beberapa grup barongan Blora menambah penampilan Buto, Warok, Perang atau Kepruk, Sulap, Lawak atau Dagelan, dan bahkan ada yang menambah dengan Klono Sewandono beserta reog Ponorogo (Kurniawan, 2017: 1). 


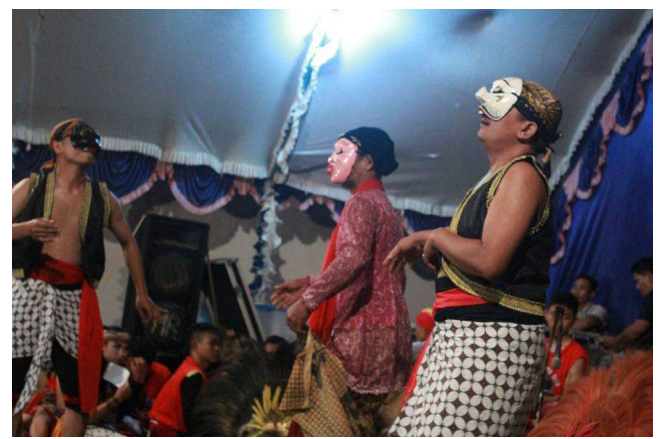

Gambar 2. Tokoh Untup, Gainah,Nayantaka dalam pentas barong Blora.

Sumber: dok.Sardula Krida Mustika.

Penambahan tokoh-tokoh di atas bertujuan untuk memperpanjang durasi dalam pementasan barongan Blora serta berhubungan dengan ciri khas antargrup barongan Blora itu sendiri. Klono Sewandono dan reog Ponorogo banyak ditampilkan grup barongan, khususnya yang berada di kawasan Kecamatan Ngawen, Randublatung, Cepu, lalu Kedungtuban, dan Kradenan. Barongan Blora umumnya ditarikan di atas panggung pada malam hari, dengan tatanan lampu dan sound system yang mendukung pementasannya. Akan tetapi masih terdapat juga pementasan barongan Blora secara lesehan atau di atas tanah. Barongan Blora biasanya dipentaskan pada acara khitanan, pernikahan, sedekah bumi, festival, maupun pembukaan dalam menyambut tamu.

Dalam pementasannya, barongan Blora menggunakan gamelan Jawa sebagai alat musik pengiringnya. Gamelan pokok dalam iringan barongan blora antara lain kendang, bonang 5 laras slendro, bonang 6 laras slendro, kethuk, kempul 6 laras slendro, kempul 2 laras slendro, saron laras slendro, demung laras slendro, dan bass drum atau yang biasa disebut jedor. Tetapi pada perkembangannya beberapa grup barongan Blora juga menambahkan beberapa alat musik, di antaranya saron pelog, demung pelog, kendang jaipong, simbal, snare drum, orgen, angklung, trompet, bahkan juga alat perkusi. Adanya berbagai alat musik tambahan biasanya digunakan untuk menyesuaikan dengan garapan musik yang diciptakan oleh komposer.

Pertunjukan barongan Blora biasanya dibuka dengan penampilan barongan atau Gembong Amijoyo. Penari menarikan dengan cara menggigit bambu berlapis selang yang melintang di dalam mulut barongan. Beberapa grup barongan Blora menarikan tokoh barongan dengan cara kucingan (bertingkah seperti gerakan harimau), tetapi ada juga yang menarikan dengan cara rampak (gerakan bersama-sama). Pada gerakan kucingan, biasanya jumlah kepala barongan yang digunakan berkisar 2 sampai 3 kepala barongan, karena sang penari membutuhkan ruang gerak yang cukup luas. Sementara itu pada gerakan rampak, bisa menggunakan jumlah kepala barongan yang lebih banyak karena pergerakan penari berhenti di tempat. Pada tarian inilah, disajikan iringan barongan Blora yang berirama keras dan dengan tempo yang cepat.

Penampilan berikutnya adalah tarian Bujang Ganong. Topeng yang 
Handep, Vol.2, No. 2, Juni 2019

digunakan berbentuk sesosok pria berhidung panjang, memiliki wajah berwarna merah, dan hanya memiliki rambut di bagian depan saja. Tarian ini biasanya dibawakan oleh penari pada tingkatan anak kecil sampai remaja. Tarian ini membutuhkan keahlian yang khusus, karena menampilkan beberapa gerakan dalam senam lantai seperti kayang, tegak bertumpu pada tangan (hand stand), tegak bertumpu pada kepala (head stand), gaya seperti kapoera, dan rol depan maupun juga rol belakang.

Pada penampilannya, beberapa grup barongan Blora memberikan selingan berupa lelucon atau lawakan yang dilakukan oleh para penari Bujang Ganong. Iringan yang sering digunakan untuk mengiringi tarian Bujang Ganong antara lain musik barongan, srempeg, lancaran, serta musik panaragan. Antargrup barongan Blora memiliki cara berbeda dalam mengiringi tarian Bujang Ganong. Tarian ini ditarikan oleh pria atau wanita yang membawa kuda lumping. Mereka akan menari dengan gerakan yang lincah dan bersama sama. Iringan yang dipakai dalam tarian jaranan pada pertunjukan barongan Blora sangat khas, yakni adanya iringan menggunakan notasi 6-5-3-2 6-5-32 2-3-5-6. Iringan ini juga yang menjadi pembeda jaranan di Blora dengan jaranan di daerah lainnya. Beberapa grup juga menambahkan berbagai tarian Jawa serta gending Jawa dalam tarian jaranan (Kurniawan, 2017: 6).
Tokoh terakhir adalah Gainah beserta Untup dan Nayantaka. Gainah merupakan tokoh wanita tua yang ditarikan oleh seorang laki-laki. Topeng Gainah biasanya berbentuk lucu dengan mulut yang miring. Dalam perkembangannya, beberapa grup juga menambahkan dengan Gainah berkarakter cantik dengan bentuk topeng menyerupai seorang gadis remaja.

Dalam tariannya, Gainah didampingi oleh Untup dan Nayantaka. Ini merupakan 2 tokoh yang menggunakan topeng berwarna hitam dan topeng berwarna putih. Bentuk topengnya cukup unik karena tidak menutupi seluruh wajah, sehingga janggut dari penari akan terlihat. Iringannya biasanya menggunakan gending-gending Jawa maupun musik-musik campursari yang sedang naik daun saat itu dan tentunya menyesuaikan zaman.

Pentas barongan Blora sangat unik dibandingkan dengan kesenian lain. Keunikan itu dapat dilihat dari setting pementasan atau wujud fisik dari barongan Blora itu sendiri.

\section{Perbedaan Barong Blora dan Barong Lain}

Barong Blora dengan barong lain sangat berbeda. Adapun barong Blora dan reog Ponorogo secara historis memang sangat berkaitan. Sebagian seniman Blora mengatakan reog atau barong Ponogoro merupakan embrio barongan Blora. Akan tetapi, akulturasi budaya dan inovasi seniman barong Blora terus 
menguatkan identitas bahwa barong Blora memiliki keunikan sendiri dan tidak sekadar klaim saja.

Meskipun hampir mirip dan sama, keduanya memiliki perbedaan yang detail. Pertama, pertunjukan barong di Bali maupun Jawa pada umumnya, erat kaitannya dengan totemisme yang dikenal dengan "Sanghiang Jarang" di Bali, dan di Jawa dikenal dengan "Jaran Kepang". Pertunjukan barongan Blora tampil berdampingan dengan Genderuwon, tokoh besar bertopeng hitam dan membawa pedang. Selain itu, tari barongan Blora jaranan ditampilkan saat sesi tersendiri. Hal inilah perbedaan seni barong Blora dengan daerah lain (Karyono, 2013: 171).

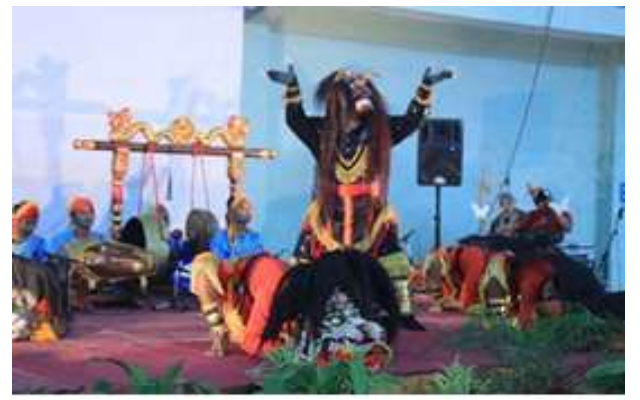

Gambar 3. Pertunjukan Barong dengan sosok Joko Lodro.

Sumber: dok.Sardula Krida Mustika.

Kedua, perbedaan barong Blora dan reog Ponorogo secara fisik, terletak pada bagian kepala. Pada kepala barong atau reog Ponorogo, terdapat bulu merak yang digambarkan sebagai sebuah keindahan. Sedangkan bentuk kepala barong Blora lebih sederhana. Kepala barong Blora hanya berupa kepala singa dengan wajah berwarna hitam yang lebih simpel atau sederhana.

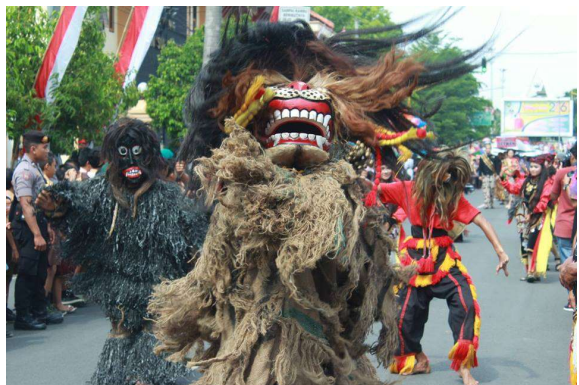

Gambar 4. Kepala Barong milik grup Sardulo Krida Mustika.

Sumber : dok. Sardula Kria Mustika.

Ketiga, dalam pertunjukan barong Blora yang tidak dimiliki kesenian barong di daerah lain karena ada sosok Genderuwo yang direpresentasikan sebagai sosok jahat dalam lakon cerita Panji Asmorobangun. Dari segi fisik, rego Ponorogo mempunyai merak, mulutnya tak bisa dibuka, menggambarkan singa. Adapun barong Blora rambutnya tak ada bulu meraknya, mulut bisa dibuka,dan menggambarkan macan.

Keempat, dilihat dari segi iringan musik saat pentas. Barong Blora lebih antusias, sedangkan pentas reog lebih santai.

Kelima, dari penokohan dalam reog, ada tokoh Klono Sewandono, dalam barongan Blora tidak ada. Dalam barongan Blora, ada tokoh Joko Lodro atau Genderuwon, dan Untub Nayantaka serta Gainah, di reog tidak ada tokoh-tokoh tersebut. 
Handep, Vol.2, No. 2, Juni 2019

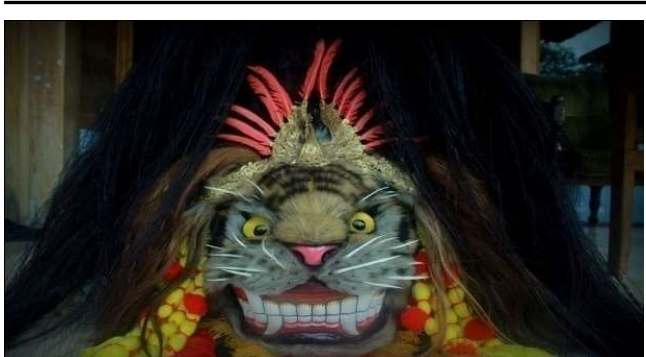

Gambar 5. Pentas Barong saat HUT Blora di Kota Blora yang menunjukkan barong dengan genderuwon.

Sumber: dok. Sardula Krida Mustika

Keenam, ada perbedaan mendasar dari aspek rohani dan aura pertunjukkan. Pancaran aura dipengaruhi oleh penampilan fisik reog Ponorogo ada bulu merak dan ukuran lebar lebih besar, sedangkan barong Blora relatif lebih kecil. Barong Blora secara wajah lebih mengindentifikasikan aura Jawanya, maksudnya Jawa di sini "Jawa Blora." Sedangkan reog Ponorogo lebih terpengaruhi setting spiritual dan khazanah budaya khas Jawa Timur dan Bali (http://www.harianblora.com/ 2014/12/inilah-perbedaan-baronganblora-dengan.html diakses pada 27 Desember 2018.

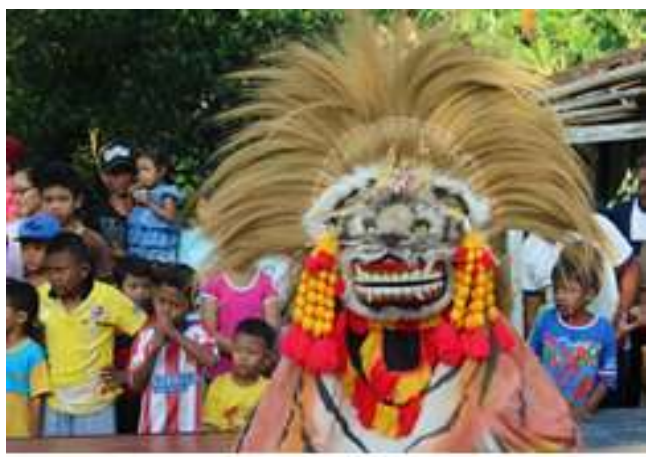

Gambar 6. Pertunjukan grup Sardulo Krida Mustika.

Sumber: dok. Sardula Krida Mustika
Hal itu sangat rasional, karena lokasi Blora berdekatan dengan Jawa Timur yang dekat dengan Kabupaten Bojonegoro, Ngawi, Ponorogo, Madiun, Magetan, dan Tuban. Barongan Blora telah memiliki identitas sendiri. Secara peralatan, tokoh Gembong Amijoyo berbentuk topeng yang bisa membuka dan menutup mulut, di mana rambutnya memakai ijuk. Tentu secara bentuk, barong Blora berbeda dengan reog Ponorogo yang memakai merak sebagai ornamennya, berbeda dengan barong di Kediri yang menampilkan lukisan serta ukiran di bagian atas barongnya, meskipun berbeda dengan barongan dari Bali. Barongan Blora memiliki tokoh yang sangat khas, di antaranya Joko Lodra, Gainah, Untup dan Nayantaka.

Tokoh Joko Lodro hanya dimiliki oleh kesenian barongan Blora. Bentuk tariannya bisa berupa tarian yang dibawakan secara tunggal, bisa secara rampak (bersama-sama), atau bisa juga ditarikan bersamaan dengan tarian pasukan jaranan. Dalam kesenian barongan Blora, tokoh Joko Lodro ini cukup vital, tidak dapat digantikan dengan tokoh lain. Tokoh ini berbeda dengan tokoh Klono Sewandono pada kesenian reog Ponorogo. Baik dari segi wajah, teknik tarian, maupun filosofinya jauh berbeda (Kurniawan, 2017: 9-10). 


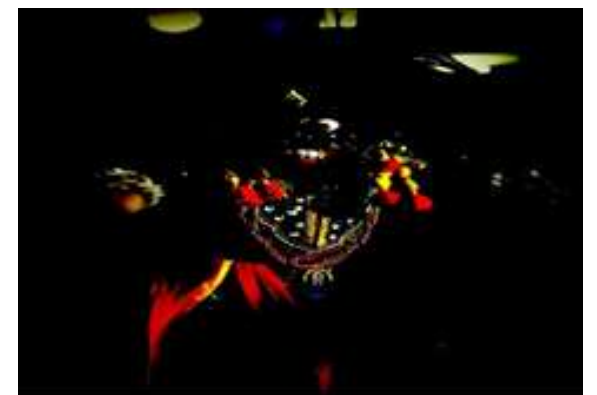

Gambar 7. Sosok Joko Lodro dalam pentas barong Blora.

Sumber: dok. Sardulo Krida Mustika.

Salah satu tokoh yang tidak kalah penting adalah Bujang Ganong. Beberapa kesenian seperti reog Ponorogo, barongan Demak, barongan Kendal, dan barongan Kediri juga memakai tokoh Bujang Ganong. Daerah Jawa Timur tampaknya menjadi kiblat dalam tarian ini, baik dari segi bentuk topeng, tarian, maupun iringannya.

Identitas dalam pertunjukan barongan Blora, tidak hanya topeng Gembong Amijoyo, tetapi juga pada penampilan tarian Bujang Ganong. Risang Guntur Seto adalah grup barongan yang pertama kali menyadari hal itu, sehingga pada tahun 2014 grup yang bermarkas di Kelurahan Kunden, Kecamatan Blora ini membuat terobosan baru, mereka mengganti bahan rambut Bujang Ganong yang biasanya terbuat dari rambut kuda ataupun dari ekor sapi bahan rayung. Rayung sendiri merupakan bahan dasar sapu yang berasal dari daerah Pemalang.

Langkah ini juga yang kemudian menjadi pelecut bagi grup lain, untuk bersama-sama mengganti rambut
Bujang Ganong dengan bahan rayung. Inovasi ini sangat patut diapresiasi, karena inilah langkah besar dalam menciptakan identitas Bujang Ganong khas Blora dalam pertunjukan barongan Blora (Kurniawan, 2017: 12-13).

Berbicara tentang musik pengiring, barongan Blora memakai iringan pokok berupa bonang 5 (limo), bonang 6 (enem), dan kempul 6 (enem). Inilah yang membuat musik barongan Blora berbeda dengan musik kesenian lainnya. Beberapa kesenian daerah di Jawa juga memakai bonang dan kempul dalam instrumen musiknya mengingat bonang serta kempul merupakan salah satu unsur utama dalam gamelan. Barongan Blora seakan telah mematenkan bonang 5, bonang 6 serta kempul 6 sebagai iringan milik barongan Blora.

Dalam tarian Bujang Ganong, grup barongan Blora banyak menggunakan musik gangsaran atau srempeg, tentu hal ini sangat berbeda dengan Bujang Ganong di daerah lain yang menggunakan iringan panaragan. Dalam tarian jaranan, iringan dengan menggunakan notasi 6-5-3-2 6-5-3-2 23-5-6 juga seakan telah paten menjadi milik barongan Blora dan berbeda dengan iringan tari jaranan di daerah lainnya. Pengembangan dalam instrumen musik memang sangat diperlukan agar barongan Blora tidak kalah bersaing dari kesenian lokal daerah lainnya. Tetapi yang perlu diingat, elemen pokok dan utama dalam musik barongan Blora tidak boleh dihilangkan (Kurniawan, 2017: 13). 
Handep, Vol.2, No. 2, Juni 2019

Mengenai kostum, masih banyak grup barongan Blora yang mengacu pada kesenian reog Ponorogo terutama dalam kostum penari Barongan, penari Bujang Ganong, dan penari jaranan. Kita tidak boleh tiba-tiba menyalahkan ataupun mempermasalahkan hal ini, karena kostum tersebut seakan telah membudaya, ditambah lagi minimnya pengerajin kostum yang ada di Kabupaten Blora sendiri, sehingga membuat banyak kostum yang didatangkan dari Kabupaten Ponorogo ataupun dari daerah lainnya. Namun upaya untuk membentuk identitas sendiri telah ada.

Sebagai contoh, grup barongan Risang Guntur Seto yang telah meninggalkan kostum penari barongan dari Ponorogo, kini diganti dengan celana komprang warna hitam polos. Selain itu, pada kostum Bujang Ganong juga tidak lagi memakai aksesoris khas Ponorogo, Adi Wibowo sebagai ketua grup barongan Risang Guntur Seto mendesain kostum khusus bagi Bujang Ganong Blora yang berbeda dengan kostum yang digunakan pada kesenian reog Ponorogo.

Contoh grup lain yang menciptakan identitas kostum khas barongan Blora adalah grup seni barong Bifang Kencana. Warsidi, sebagai ketua grup barongan Blora ini menciptakan kostum jaranan khas Blora yang juga memiliki perbedaan sangat menonjol apabila dibandingkan dengan kostum jaranan di daerah lainnya (Kurniawan, 2017: 14).

Upaya seperti ini sangat baik untuk terus dilakukan demi terciptanya sebuah identitas barongan Blora. Apabila suatu identitas telah terbentuk, maka kesenian itu sendiri akan lebih mudah diingat oleh masyarakat luas, sehingga akan lebih mempermudah untuk kepentingan promosi kesenian barongan Blora di ruang lingkup yang lebih luas.

Barongan Blora memiliki keunikan, namun harus menyesuaikan zaman tanpa mengubah subtansi dan nilai-nilai kebudayaan dalam bentuk fisik maupun non-fisiknya. Oleh karena itu, semua seniman harus berinovasi untuk menghadapi perubahan dan juga tantangan zaman.

\section{Profil Grup Barong Sardulo Krida Mustika}

Sardulo Krida Mustika merupakan salah satu grup barong remaja yang didirikan sejak tahun 2014 yang beralamat di Dukuh Triteh, Desa Tambahrejo RT.3 RW.1, Kecamatan Tunjungan, Kabupaten Blora. Awalnya, grup ini hanya berawal dari inisiatif seniman muda, Indra Bagus Kurniawan dari Risang Guntur Seto yang menjadi senior grup barong di Blora, bahkan di Jawa Tengah.

Pada akhir tahun 2016, Sardulo Krida Mustika merupakan nama baru grup barong yang sebelumnya bernama grup Dinindra Jaya. Makna Sardulo Krida Mustika ini sangat erat kaitannya dengan semboyan "Blora Mustika." Sardulo diambil dari filosofi reog Ponorogo. Krida bermakna perbuatan atau olahraga. Mustika adalah mustika, permata atau emas. 


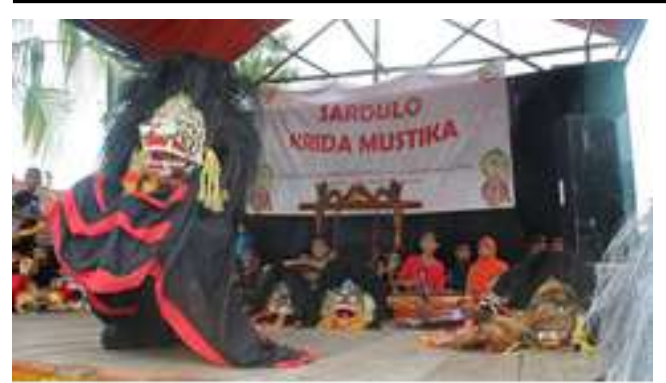

Gambar 8. Pentas barong Sardulo Krida Mustika di acara warga. Sumber: dok. Sardulo Krida Mustika.

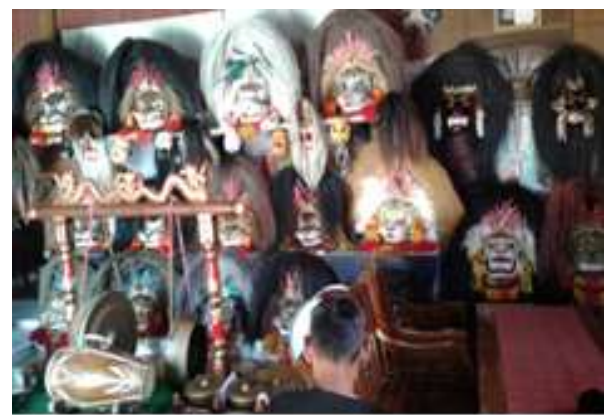

Gambar 9. Sebagian peralatan barongan milik Sardulo Krida Mustika.

Sumber: dok. Sardulo Krida Mustika.

Keunikan dari Sardulo Krida Mustika tidaklah untuk mencari materi atau uang pentas. Namun, mereka lebih mengutamakan pada sisi edukasi untuk anak-anak, remaja, dan mahasiswa.

Grup Sardulo Krida Mustika, minimal memiliki 30 personel saat pementasan. Untuk pengrawit berjumlah 11 orang, pembarong 5 orang, jaranan 8 orang, pemain Gainah dan Bujang Ganong 2 orang, Joko Lodro 1 orang, dan pemeran Untup, Nayantaka 3 orang.

Meskipun mengutamakan aspek edukasi, namun Sardulo Krida Mustika tidak kalah laris dengan grup-grup barong lain yang dari awal pendirian fokus pada komersial. Hingga 2018, baik perorangan atau secara grup, Sardulo Krida Mustika sudah pentas di acara Bhayangkari Polres Blora, SMPN 6 Blora, SMPN 1 Blora, SMAN 1 Tunjungan, Poltekkes Kemenkes Semarang, Undip, Unnes, Unwahas, SDN Sampangan 01 Kota Semarang, Desa Nglebak, Kradenan, Blora, Festival Barong Nusantara, HUT Risang Guntur Seto, pentas di Rembang, dan di beberapa daerah lain.

Saat wawancara, Indra Bagus Kurniawan, pimpinan Sardulo Krida Mustika menyatakan tujuan dan kegiatan Sardulo Krida Mustika sejak awal dibentuk.

"Kita spesialis garapan, bukan pentas. Tujuan utama kami mendirikan grup ini juga tidak untuk komersil. Namun lebih dominan edukasi, hobi, dan untuk menyalurkan bakat serta mengajak generasi muda melestarikan tradisi barong" (Wawancara Indra Bagus Kurniawan, Blora, Desember 2018).

Sampai tahun 2018, grup Sardulo Krida Mustika memiliki peralatan yang dipakai latihan, promosi, atau pementasan yang terdokumentasikan rapi. Selain dibeli, peralatan ini juga berasal dari hasil buah tangan dan inovasi yang dilakukan anggota grup Sardulo Krida Mustika, khususnya pada barong. 
Handep, Vol.2, No. 2, Juni 2019

Berikut daftar peralatan grup

Sardulo Krida Mustika:

1. Gamelan Jawa/Saron (laras slendro dan pelok
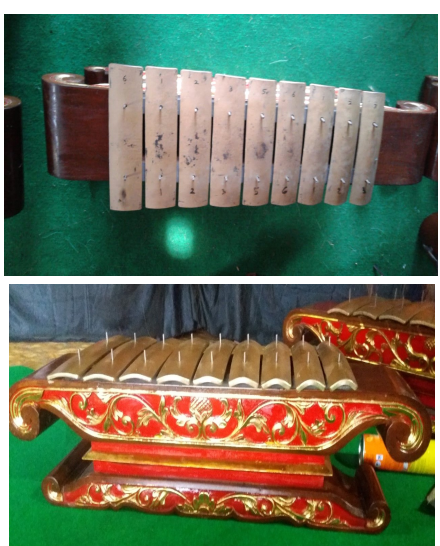

Sumber: dok. Sardulo Krida Mustika.

2. Kendang dan Plangkan (tempat kendang)

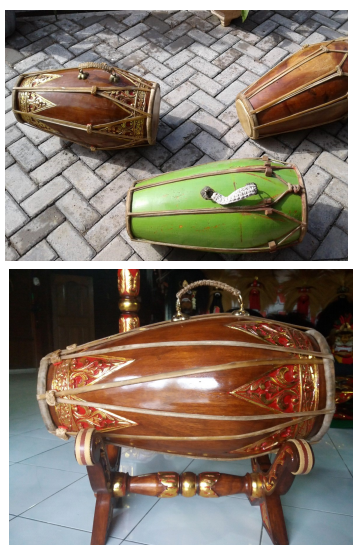

Sumber: dok. Sardulo Krida Mustika.

\section{Gong}

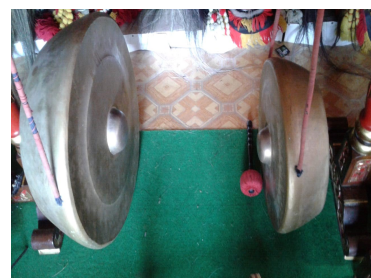

Sumber: dok. Sardulo Krida Mustika.
4. Gayor (tempat gong)

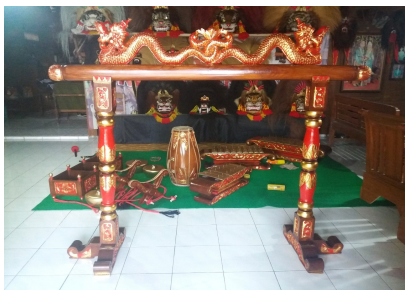

Sumber: dok. Sardulo Krida Mustika.

5. Bonang (2 buah) dan Kethuk (1 buah)

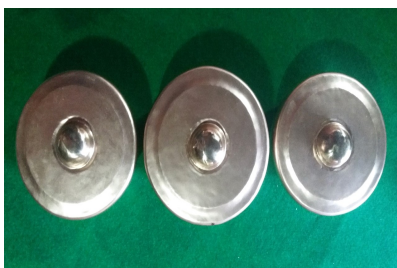

Sumber: dok. Sardulo Krida Mustika.

6. Kempul

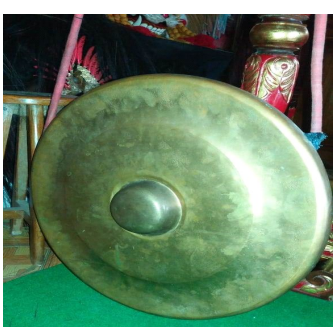

Sumber: dok. Sardulo Krida Mustika.

7. Demung

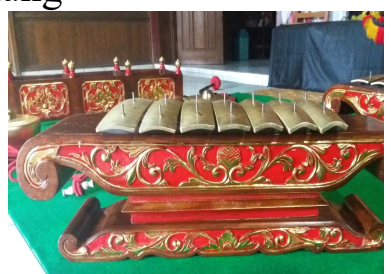

Sumber: dok. Sardulo Krida Mustika.

8. Ketipung

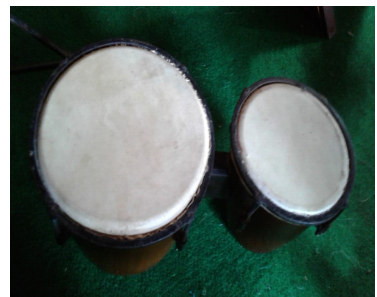

Sumber: dok. Sardulo Krida Mustika. 


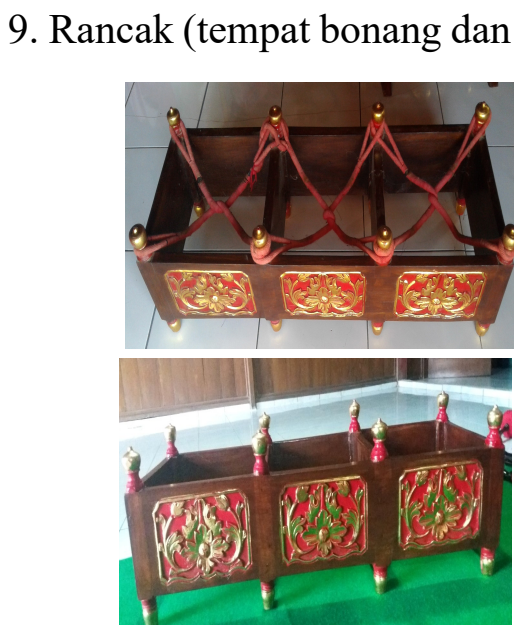

Sumber: dok. Sardulo Krida Mustika.

\section{Barongan}

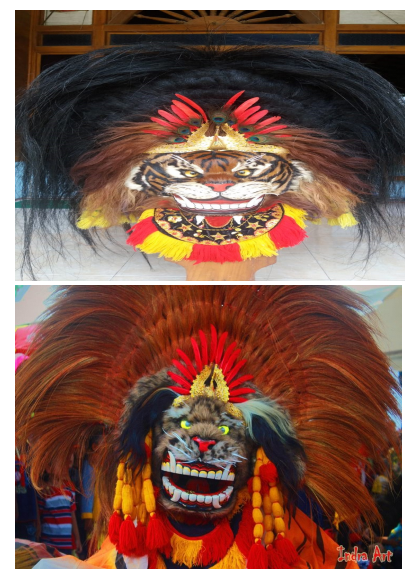

Sumber: dok. Sardulo Krida Mustika.

\section{Bujang Ganong}

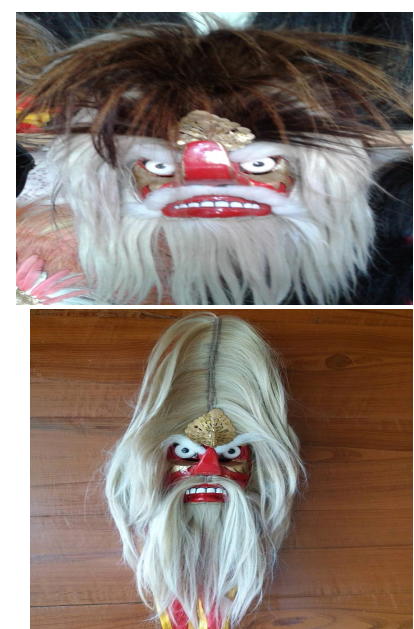

Sumber: dok. Sardulo Krida Mustika.
12. Joko Lodro (Genderuwon)

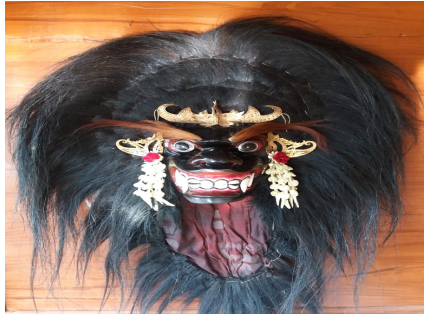

Sumber: dok. Sardulo Krida Mustika.

13. Untup

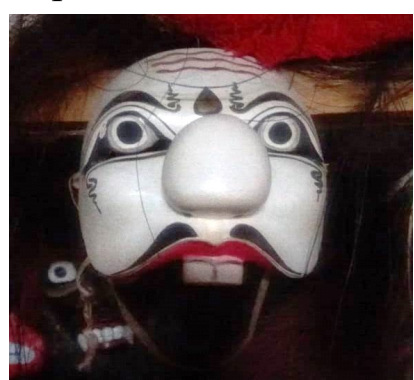

Sumber: dok. Sardulo Krida Mustika.

14. Nayantoko

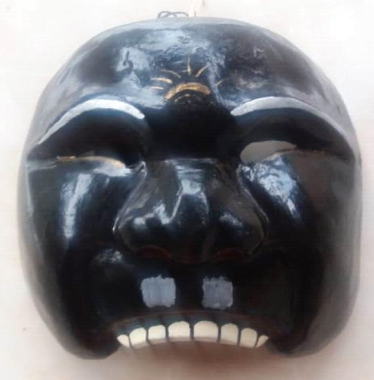

Sumber: dok. Sardulo Krida Mustika.

\section{Gainah}

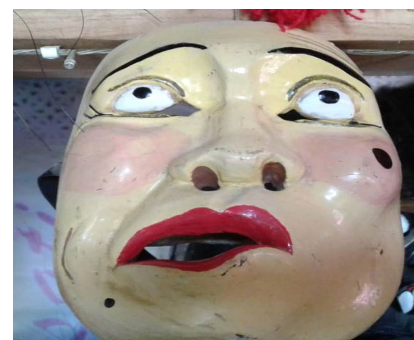

Sumber: dok. Sardulo Krida Mustika. 
Handep, Vol.2, No. 2, Juni 2019

16. Jaranan

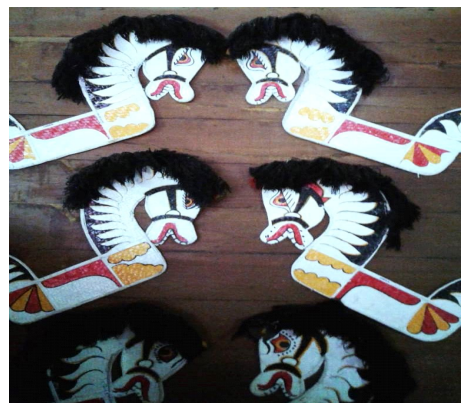

Sumber: dok. Sardulo Krida Mustika.

17. Simbal dan Snare

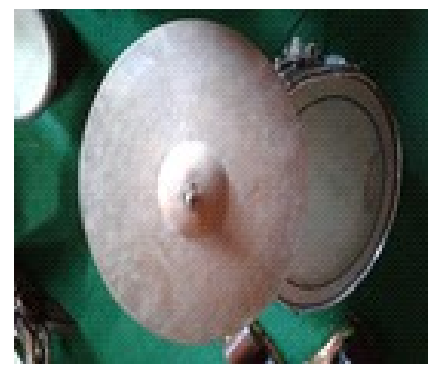

Sumber: dok. Sardulo Krida Mustika

Secara umum, kegiatan grup Sardulo Krida Mustika hampir sama seperti grup barong lain. Namun, yang unik pada grup ini tidak ada orientasi utama mencari uang atau komersil, melainkan lebih pada aspek edukasi dan pelestarian budaya.

Grup ini melakukan latihan setiap dua minggu sekali bahkan seminggu sekali di basecamp. Latihan dilaksanakan hari Sabtu malam dan hari Minggu karena mayoritas anak-anak, pelajar, dan mahasiswa libur pada hari tersebut. Latihan dilaksanakan tidak sekedar saat akan ada pentas atau tanggapan (panggilan) dari warga, pemerintah desa, atau instansi di wilayah Blora, Rembang, Demak, Grobogan, dan Semarang. Latihan dilaksanakan setiap dua kali seminggu untuk memperkuat keterampilan pentas, dan melakukan inovasi atau menggarap lagu-lagu baru yang dapat digunakan saat pentas.

\section{Strategi Sardulo Krida Mustika Melestarikan Seni Barongan}

Tidak semua grup barong di Kabupaten Blora memiliki strategi atau inovasi tinggi untuk melestarikan kesenian lokal ini. Kebanyakan grup barong di Blora hanya berjalan natural tanpa visi melestarikan, karena kebanyakan hanya ingin terkenal dan mendapat permintaan banyak. Padahal, grup barong di Blora begitu banyak dan yang paling laris mendapat permintaan tanggapan dari masyarakat grup sudah senior.

Dari hasil wawancara, ada beberapa strategi yang sudah dilakukan dan akan dilakukan grup barong Sardulo Krida Mustika dalam melestarikan kesenian barongan Blora. Pertama, memanfaatkan teknologi perkembangannya yang begitu pesat untuk ajang sosialisasi, promosi, dan branding Blora Kota Barongan. Hal itu sudah dilakukan personel Sardulo Krida Mustika, baik di Facebook, Twitter, Instagram, dan Youtube.

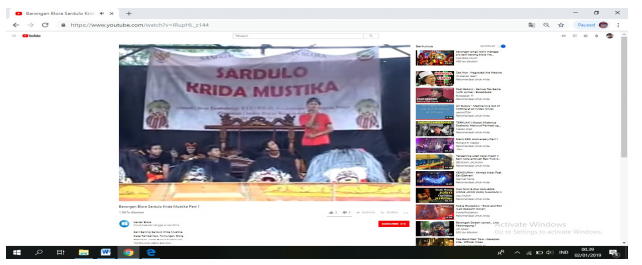

Gambar 10. Video pentas Sardulo Krida Mustika di Youtube

Sumber: https://www.youtube.com/ watch? $v=1$ RupHL z14), diakses pada Desember 2018 
Kedua, melakukan kerjasama dengan media siber seperti yang sudah terlaksana dengan media online $\mathrm{H}$ a $\mathrm{r}$ i a $\mathrm{n} \mathrm{j}$ a $\mathrm{t}$ e $\mathrm{ng}$. c o m, $\mathrm{H}$ a ri a $\mathrm{n}$ s e m a r a g . c o m, Harianblora.com, Harianguru.com, serta Koranpati.com. Melalui pemberitaan positif tentang aktivitas Sardulo Krida Mustika, maka apa saja yang dilakukan anggota grup dapat diakses masyarakat secara luas, bahkan yang berada di luar Jawa.

Ketiga, mengikuti perkembangan zaman dengan cara memoles desain barong yang menarik. Wajah barong harus menarik, tidak boleh asal-asalan. Apalagi setiap perajin barong memiliki keunikan dan ciri khas sendiri terkait polesan wajah dan rambut barong.

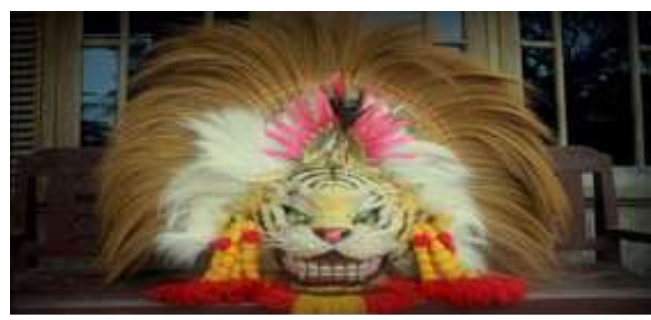

Gambar 11. Salah satu hasil inovasi barong

Sardulo Krida Mustika berambut rayung, dan berkulit bukan dari kulit hewan asli. Sumber: dok. Sardulo Krida Mustika.

Keempat, merintis kerajinan barong secara mandiri pada anggota grup. Selain berlatih dan beratraksi Sardulo Krida Mustika juga sejak tiga tahun terakhir telah melebarkan sayap membuat barong secara mandiri dengan inovasi dan ciri khas yang dikembangkan. Seperti contoh rambut barong, kebanyakan memakai rambut dari dhuk (ijuk pohon aren), namun Sardulo Krida Mustika mulai mengembangkan barong berambut rayung (tangkai pelepah rumput gelagah).

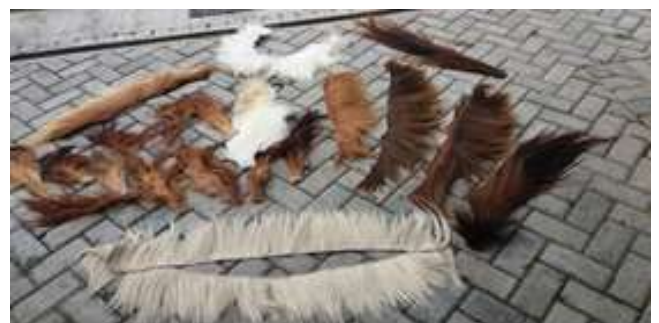

Gambar 12. Kulit sapi, kambing untuk pembuatan rambut barong.

Sumber: dok. Sardulo Krida Mustika.

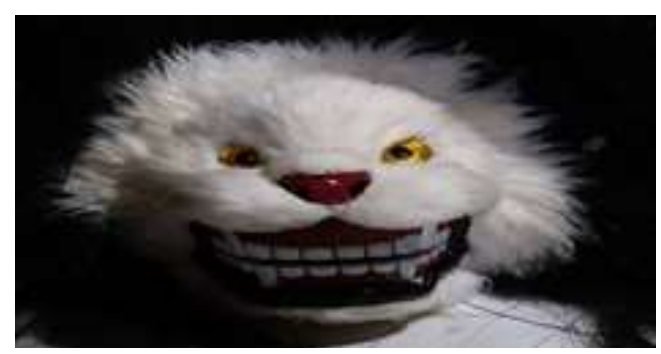

Gambar 13. Pembuatan kepala singo barong secara mandiri.

Sumber: dok. Sardulo Krida Mustika.

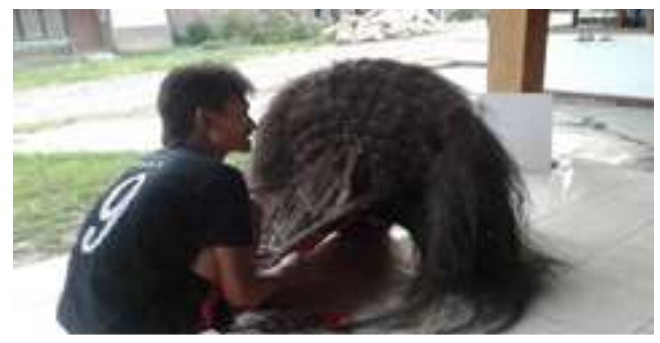

Gambar 14. Tahap pemberian rambut pada kepala singo barong.

Sumber: dok. Sardulo Krida Mustika.

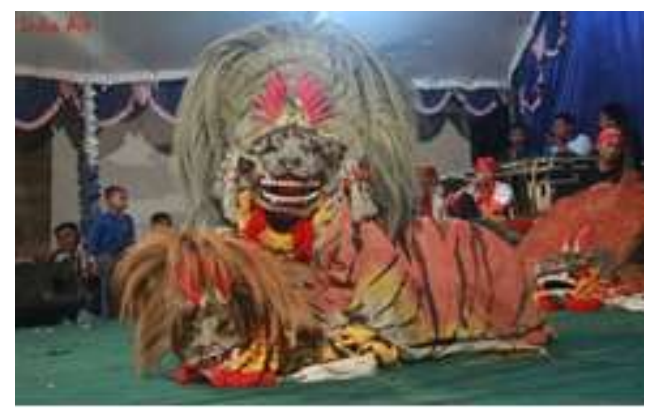

Gambar 15. Barongan hasil inovasi grup Sardulo Krida Mustika berambut rayung saat pentas.

Sumber: dok. Sardulo Krida Mustika. 
Handep, Vol.2, No. 2, Juni 2019

Kelima, mengutamakan sisi edukasi daripada komersil dan uang. Hal ini justru menjadikan para personel Sardulo Krida Mustika diundang menjadi guru ekstrakurikuler di beberapa sekolah seperti SDN Tutup 01 Blora, SMPN 1 Blora, SMAN 1 Blora, bahkan juga di SDN Sampangan 01 Kota Semarang, dan mendampingi kegiatan di sejumlah sekolah negeri maupun swasta di sejumlah kecamatan di Blora.

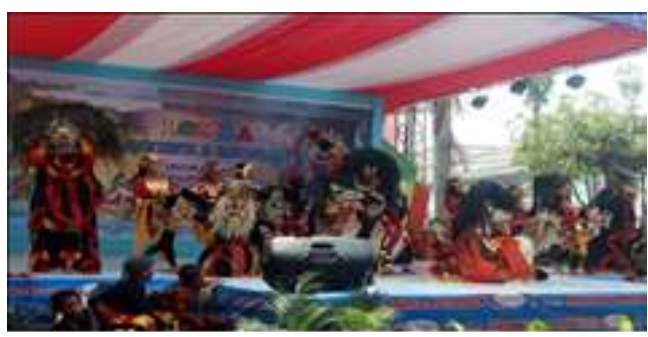

Gambar 16. Grup barong anak SDN Tutup 01 Blora binaan Sardulo Krida Mustik yang tahun 2018 mendapat Juara I Lomba Bercerita \& Barongan. Sumber: dok. Sardulo Krida Mustika.

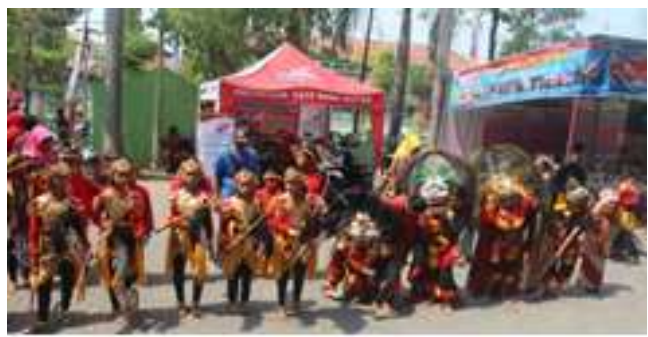

Gambar 17. Siswa-siwi SD binaan Sardulo Krida Mustika.

Sumber: dok. Sardulo Krida Mustika.

Indra Bagus Kurniawan, Pemimpin Sardulo Krida Mustika menyatakan, edukasi menjadi ruh grupnya dalam melestarikan tradisi tersebut.
"Edukasi bagi kami adalah nyawa dalam berkarya. Baik berkarya dalam pentas, inovasi langgam, tari, atau inovasi dalam pembuatan barong itu sendiri. Kami menekankan kepada semua personel untuk lebih mendahulukan edukasi budaya dan tidak berharap pendapatan. Kalau berharap keuntungan materi tidak akan untung, karena modal bermain barong sangat mahal, baik dari segi harga barong, atau semua peralatan, make up, sound system dan lainnya" (Wawancara Indra Bagus Kurniawan, Blora, Desember 2018).

Keenam, kerjasama dengan grup barong lain dengan cara mengambil satu, atau dua orang saat ada pentas. Apalagi, kebanyakan seniman barong di Blora, satu orang bisa menjadi anggota banyak grup. Hal inilah yang menjadikan seniman itu akan tetap lahir dan banyak pemuda tertarik menjadi seniman, karena selain banyak teman, mereka juga dapat hidup, dan sekolah secara mandiri lewat pendapatan dari hobi tersebut.

Ketujuh, memperbanyak anggota usia SD, SMA, dan mahasiswa. Hingga tahun 2018 terdapat 36 anggota. Anggota rutin latihan dengan memilih latihan setiap liburan (Sabtu, Minggu, atau hari libur nasional). Dengan demikian, mereka akan terus latihan tanpa mengganggu waktu belajar. 


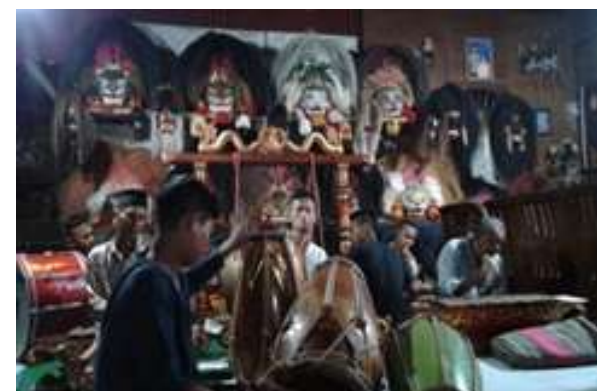

Gambar 18. Latihan rutin anggota dan pembina grup Sardulo Krida Mustika. Sumber: dok. Sardulo Krida Mustika.

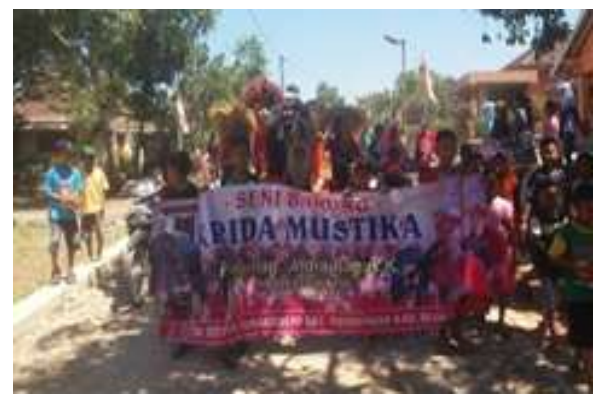

Gambar 19. Melibatkan anak-anak dan pelajar dalam pentas barong di luar panggung, dengan cara arak-arakan dalam acara di desa-desa.

Sumber: dok. Sardulo Krida Mustika.

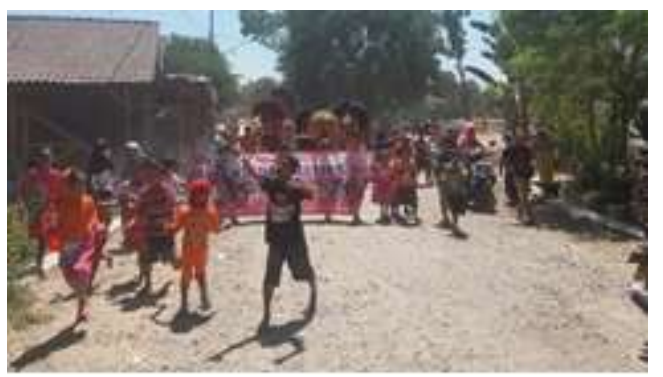

Gambar 20. Antusiasme warga khususnya anak-anak dan pelajar dalam pentas barong di luar panggung, dengan cara arak-arakan dalam acara di desa-desa.

Sumber: dok. Sardulo Krida Mustika.

Kedelapan, menjadikan aktivitas seni barong untuk berbinis dan melatih kemandirian secara ekonomi. Pola dan doktrin "berkarya seni dan berbisnis" selalu ditanamkan kepada para anggota grup. Sardula Krida Mustika menggagas
"Baronganpreneurship" atau wirausaha barongan. Akan tetapi, yang dijual bukanlah pentasnya, melainkan barong secara fisik melalui pemanfaatan media sosial tiap personel. Setiap kali penjualan, misalnya, barong, genderuwon, dan gamelan mampu menghasilkan laba atau keuntungan bersih dari Rp. 100.000 hingga Rp. 1.000.000.

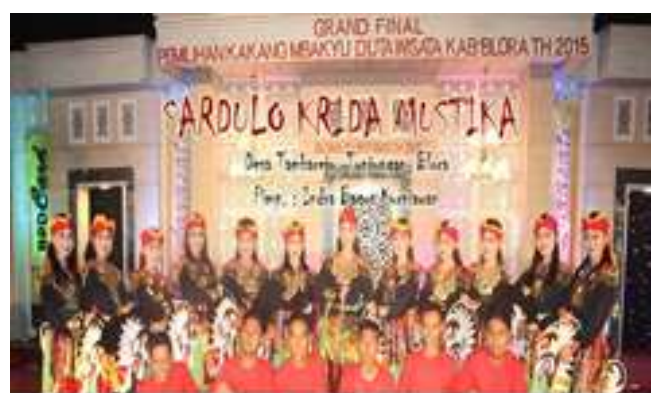

Gambar 21. Banner promosi di media sosial untuk menarik minat dan branding grup Sardulo Krida Mustika.

Sumber: dok. Sardulo Krida Mustika.

Kesembilan, bekerjasama, menjalin komunikasi dengan organisasi mahasiswa dan perantau Blora, baik di wilayah Blora, Jawa, Jakarta, luar Jawa bahkan di luar negeri. Seperti, Ikatan Mahasiswa Pelajar Blora (Impara), Keluarga Mahasiswa Blora (Kamaba), Komunitas Perantau Blora (Kopra), dan Komunitas Masyarakat Blora (Komara). Bentuk kerjasama yang sudah dilakukan berupa peminjaman alat musik barong, sing barong, genderuwon, atau saling membantu personel ketika pentas.

Usaha-usaha pelestarian yang dilakukan Sardulo Krida Mustika sudah selaras dengan konsep dan teori fungsionalisme struktural Talcott 
Handep, Vol.2, No. 2, Juni 2019

Parsons. Alasannya karena teori fungsionalisme struktural Parsons diawali dengan empat skema penting mengenai fungsi untuk semua sistem tindakan, skema tersebut dikenal dengan sebutan skema AGIL (Adaptation, Goalattainment, Integration, Latent-patern-maintenance) yang dapat dilakukan untuk melestarikan sebuah kebudayaan (Ritzer, 1992: 102105).

Keempat skema tersebut telah dilakukan grup Sardulo Krida Mustika untuk melestarikan dan menjaga keberadaan barong.

Pada skema adaptation, grup ini telah melakukannya pada strategi 1,2 , 3, 4, 7, 8, 9. Adaptasi ini dilakukan dengan cara beradaptasi dalam mempertahankan seni barong sesuai perkembangan zaman atau spirit zaman (zeitgeist).

Pada skema goal (tujuan), grup Sardulo Krida Mustika telah melakukannya pada strategi 5. Grup ini tidak sekadar memburu uang dan nama, namun mengutamakan aspek edukasi kepada anak-anak, pelajar, dan mahasiswa sebagai calon penerus budaya lokal tersebut.

Pada skema integration (integrasi), grup Sardulo Krida Mustika telah melakukan strategi 1 dan 2 yaitu mengintegrasikan pendekatan manual menuju digital. Integrasi juga dilakukan pada aspek pemertahanan budaya dan merintis bisnis yang terlaksana pada strategi nomor 8 . Sedangkan integrasi pada personel, pertunjukan, dan kolaborasi antargrup, dilakukan pada strategi nomor 6 dan 9. Semua itu dapat dilakukan dengan adanya dukungan dan relasi antara personel, sekolah, media massa, seniman yang dekat dengan grup Sardulo Krida Mustika.

Pada skema latensi atau pemilihan pola-pola yang sudah ada (pattern maintance), grup Sardulo Krida Mustika telah mempertahankan, memperbaiki, baik motivasi individu maupun pola budaya yang menciptakan dan mempertahankan barong melalui anggota grup yang terdiri atas anakanak, pelajar, mahasiswa, maupun kolega pada grup lain, dan masyarakat. Kebutuhan dasar anak-anak dan pemuda di Blora tidak hanya bermain dan menonton barong dalam pentas secara langsung, namun juga membutuhkan pentas barong dalam bentuk audio visual di media massa, media sosial, dan Youtube.

\section{SIMPULAN}

Pembahasan hasil penelitian di atas, dapat disimpulkan ke dalam beberapa poin. Pertama, barongan Blora merupakan kesenian khas Jawa Tengah yang paling banyak ditemukan di Blora. Lantaran demikian, Blora mendedikasikan diri sebagai "Kota Barongan" dan sudah diakui Kemdikbud RI dan Dinas Pendidikan dan Kebudayaan Jawa Tengah bahwa barongan Blora sudah masuk Warisan Budaya Takbenda (WBTB). Barongan Blora merupakan kesenian kerakyatan asli Kabupaten Blora, Jawa Tengah. Bentuk dari kesenian ini adalah berupa pertunjukan tari yang di dalamnya 
menampilkan tokoh Barongan atau Gembong Amijoyo, Bujang Ganong, Joko Lodro atau Gendruwon, Untup, Nayantaka, Gainah, dan Jaranan atau Jatilan.

Kedua, Sardulo Krida Mustika merupakan salah satu grup barongan Blora yang berdiri sejak 2014. Keunikan grup ini selain fokus pada sisi edukasi, mereka juga mengembangkan "baronganpreneur".

Ketiga, ada beberapa perbedaan mendasar barongan Blora dengan barongan lain termasuk reog Ponorogo. Baik dari sisi fisik, penokohan, pengiring musik saat pentas, maupun dari sisi spiritual atau mitologi.

Keempat, ada sembilan (9) strategi yang dilakukan grup Sardulo Krida Mustika untuk melestarikan, menguatkan, dan menggerakkan barongan Blora sebagai khazanah budaya Nusantara ini. Dari sembilan strategi pelestarian barong Blora yang dikembangkan Sardulo Krida Mustika tersebut sesuai Konsep AGIL (adaptation, goalattainment, integration, latent-patern-maintenance) dalam teori fungsionalisme struktural Talcott Parsons. Dengan demikian sembilan strategi ini dapat juga diterapkan pada grup-grup barong lain.

\section{DAFTAR SUMBER}

Barongan Blora Resmi Diakui Sebagai Warisan Budaya Takbenda, Jangan Diklaim Ya." diunduh dari http:// www.infoblora.com/2017/12/ barongan-blora-resmi-diakuisebagai.html, pada 29 Desember 2018.
Barongan Gembong Amijoyo, https:// id.wikipedia.org/wiki/ Barongan_Gembong_Amijoyo, diakses pada Desember 2018.

Bintartiwi, H. I. 2014. Sejarah Kesenian Barongan di Desa Kunden Kecamatan Blora. Skripsi. Salatiga: FKIP Universitas Kristen Satya Wacana.

Creswell, J. W. 2009. Research Design Pendekatan Penelitian Kualitatif, Kuantitatif, dan Mixed (1st ed.). Yogyakarta: Pustaka Pelajar.

Fauzin, A., Membumikan Blora Kota Barongan, diunduh dari www.islamcendekia.com/2014/06/ membumikan-blora-kotabarongan.html, pada Juni 2014.

Https://www.harianblora.com/2014/12/ inilah-perbedaan-barongan-bloradengan.html, pada 27 Desember 2018.

Https://id.wikipedia.org/wiki/ Barongan_Gembong_Amijoyo, diakses pada Desember 2018.

https://www.youtube.com/ watch?v=1RupHL_z14), diakses pada Desember 2018.

Hutomo, S. S. 1996. Tradisi dari Blora (1st ed.). Semarang: Citra Almamater.

Jedoran, Rebana Tradisional Khas Blora yang Hampir Punah, diunduh dari http:// www.infoblora.com/2013/05/ jedoran-rebana-tradisional-khas- 
Handep, Vol.2, No. 2, Juni 2019

blora.html, pada 28 Desember 2018.

Keswara, R., Kurang Perlindungan, Ratusan Budaya Tradisional Punah, diunduh dari nasional. sindonews.com/read/776518/15/ kurang-perlindungan-ratusanbudaya-tradisional-punah1377684089, pada Agustus 2013.

Kurniawan, I. B. 2017. Sisi Lain Barongan Blora (1st ed.). Semarang: CV. Pilar Nusantara.

Model Pertunjukan Barongan Anak sebagai Transmisi Budaya Daerah. Greget Jurnal Pengetahuan Dan Penciptaan Tari, 12 No. 2, hlm. 171-185.

Nugroho, P. D. P, Mau Peduli Budaya Indonesia? Tonton Dulu Barongan di Blora, diunduh dari regional. kompas.com/read/2017/12/06/ 10284921/mau-peduli-budayaindonesia-tonton-dulu-barongandi-blora, pada Desember 2017.

Pemerintah Kabupaten Blora. Seniman Barongan, diunduh dari www.blorakab.go.id/index.php/ public/kebudayaan/detail/59/ senian-barong\%0A, pada 28 Desember 2018.

Purwaningrum, A., Tradisi Indonesia 10 Adat Istiadat Unik Khas Nusantara Ini Hampir Punah, Berani Ikut Lestarikan?, diunduh dari http://travel.tribunnews.com/ 2017/01/24/tradisi-indonesia-10adat-istiadat-unik-khas-nusantaraini-hampir-punah-berani-ikutlestarikan?, pada 24 Januari 2017.

Rachma, D., Kabupaten Blora dan Kesenian Tradisional Barongan, diunduh dari www.goodnewsfromindonesia.id/ 2016/12/05/kabupaten-blora-dankesenian-tradisional-barongan, pada 5 Desember 2016.

Ranjabar, Jacobus dan Risman F. Sikumbank. 2006. Sistem Sosial Budaya Indonesia: Suatu Pengantar (1st ed.). Bogor: Ghalia Indonesia.

Ritzer, G. 1992. Sosiologi Ilmu Pengetahuan Berparadigma Ganda (1st ed.). Jakarta: Rajawali Pers.

Slamet dan Soedarsono, R. N., 1999. Barongan Blora dalam Ritus Lamporan: Kelangsungan dan Perubahannya. Sosiohumanika, 12 (2), hln. 131-140.

Statistik Kebudayaan 2016, diunduh dari http://publikasi.data. kemdikbud.go.id/uploadDir/ isi $5808 \mathrm{~B} 5 \mathrm{CD}-\mathrm{F} 78 \mathrm{~A}-4 \mathrm{~A} 7 \mathrm{C}$ A886-3DB9D1CF688B_.pdf, pada Desember 2018.

Sutomo, Y., Kesenian Khas Blora Nyaris Punah, diunduh dari www.liputan6.com/news/read/ 196766/kesenian-khas-blora- 
nyaris-punah, pada Desember 2008 .

Wawancara. Indra Bagus Kurniawan. Blora, 15/20 Desember 2018.

Wawancara. Sumardjan. Blora, 27 Desember 2018.

Wiyono, A. S., 15 Bahasa Daerah di Indonesia Punah, 139 Terancam Lenyap, diunduh dari www.merdeka.com/peristiwa/15bahasa-daerah-di-indonesia-punah139-terancam-lenyap.html, pada Agustus 2016. 
Handep, Vol.2, No. 2, Juni 2019 